TECHNICAL TRANSACTIONS 7/2018

CIVIL ENGINEERING

DOI: $10.4467 / 2353737$ XCT.18.103.8798

\author{
Tomasz Szczuraszek \\ Marcin Karwasz (marcin.karwasz@utp.edu.pl) \\ Department of Road and Transport Engineering, UTP University of Science and \\ Technology
}

\title{
TRANSPORT ATTRACTIVENESS OF SHOPPING MALLS
}

\section{ATRAKCYJNOŚĆ TRANSPORTOWA WIELKOPOWIERZCHNIOWYCH \\ OBIEKTÓW HANDLOWO-USŁUGOWYCH}

\begin{abstract}
The dynamic development of analytical methods used for the modelling of town travel increases the demand for various kinds of data necessary to estimate the road traffic volume on transport networks. The estimation of traffic volume generated by particular facilities located in a city is an important element of modelling. Among these facilities, large shopping malls are considered to be one of the most significant road traffic generators. The estimation of transport attractiveness of such large objects is a big challenge in modelling customers' journey to large shopping malls. In this study, a new method is proposed for the assessment of transport attractiveness of large trade and service facilities.
\end{abstract}

Keywords: shopping malls, attractiveness, road traffic modelling

\section{Streszczenie}

Dynamiczny rozwój metod analitycznych stosowanych do modelowania podróży w mieście prowadzi do wzrostu zapotrzebowania na coraz większą liczbę różnorodnych danych niezbędnych do szacowania wielkości ruchu drogowego na sieciach transportowych. Istotnym elementem modelowania jest szacowanie wielkości ruchu generowanego przez poszczególne obiekty zlokalizowane w mieście. Wśród tych obiektów to wielkopowierzchniowe centra handlowo-usługowe są jednymi z największych generatorów ruchu drogowego. Dużym wyzwaniem przy modelowaniu podróży do centrów handlowo-usługowych jest oszacowanie atrakcyjności transportowej tych obiektów. W niniejszym artykule przedstawiono autorską metodę określania atrakcyjności transportowej wielkopowierzchniowych obiektów handlowo-usługowych.

Słowa kluczowe: centra handlowe, atrakcyjność, modelowanie ruchu drogowego 


\section{Introduction}

A city's transportation systems can be described as being its 'blood circulatory system. The efficiency of such systems and the role they play in the urban structure is one of the major factors determining the growth of a city and the level of satisfaction of its. In turn, the inappropriate development of transport systems and poor decisions on infrastructure design and management result in many problems including road congestion, the inefficiency of public transport systems, economic loss and degradation of the environment.

Along with the technological progress in different areas of economic and social life, we obtain a variety of tools which can be used for the active management of city space, including processes which occur in town transport networks. The development of computer technologies that support town management and enable the processing of a large amount of data, collected from different systems, provides a great potential to obtain precious information about the state of transport and allows the prediction of outcomes of given decisions. Currently, active town management, through such strategies as the introduction of intelligent transport systems (ITS) to support road infrastructure and transport decision makers in the analysis and processing of data on road congestion, is gaining more and more popularity. Many planning studies use complicated spatial analyses of passenger and freight transportation systems. All of these modern solutions provide the possibility to increase the efficiency of transport systems through prediction and better insight into the phenomena which occur on the road.

In order to be able to correctly manage the city road network, it is necessary to identify the road traffic volume as well as the inhabitants' transport needs and behaviours. Correct determination of the traffic volume and the size predicted infrastructure loading with traffic is very important. This provides the basis for effective planning and management of transport systems, particularly road infrastructure, extension. In order to determine the road traffic volume, it is necessary to identify objects and areas which generate significant transport streams and simultaneously affect the inhabitants transport related behaviours. Large shopping malls are certainly an example of such places which generate traffic volume.

Large shopping malls, are facilities with significant areas that are used for trade and services. They integrate many attractive services offering entertainment, shopping, and dining facilities, and are a popular destination for a vast number of people. The high concentration of visitors generates high volume transport streams, which place a significant load on the transport infrastructure, especially within the immediate vicinity of the shopping malls. The rapid increase in the number of such objects in Poland within the last twenty-five years has posed significant problems for urban road networks. Subsequently, the determination of the number of journeys that are likely to be generated as a result of these objects and the spatial arrangement for particular modes of transport used for the journeys is a very important task. The assessment of the transport attractiveness of these facilities, providing a synthetic and comparative description of a given facility in terms of its popularity, is pretty challenging. In order to identify this quantity, a series of field experiments have been carried out and an original method to be used for assessment of shopping mall transport attractiveness, has been developed. 


\section{Field experiments of the evaluation of shopping mall transport attractiveness}

The tests involved surveying customers of shopping mall facilities and the estimation of the number of shopping mall visitors. The surveys included 700 respondents and were carried out in eleven shopping malls, located in five Polish urban locations (towns and cities). In order to carry out the surveys, for specific groups of individuals (groups of persons with the same transport-related behaviours), on the basis of the following formula [2]:

$$
N_{\min }=\frac{N_{p} \cdot Z_{\alpha}^{2} \cdot f(1-f)}{N_{p} \cdot d^{2}+Z_{\alpha}^{2} \cdot f(1-f)},
$$

where:

$N_{p}$ - the population of the sample, the number of potential customers of shopping malls in Poland was accepted as $\mathrm{N}_{\mathrm{p}} \approx 30 \mathrm{mln}$. [inhabitants]

$Z_{\alpha}$ - the value of the standardised normal variable $\mathrm{N}(0,1)$ for a fixed value $1-\alpha$, was accepted as 1.88 for $\alpha=0.06$ [-]

$f$ - the value of the fraction was set on the basis of own study for particular groups of people with comparable transport behaviours: schoolchildren 0.145; students: 0.038; employed: 0.479 ; unemployed: 0.338 [-]

$d$ - the maximal error was assumed to be $0.06[-]$

The following, minimal survey populations were formed for specific groups of comparably behaving people on the basis of equation (1): schoolchildren, 122; students, 36; employed, 245 ; unemployed, 220 . The abovementioned requirements concerning minimal populations were met for the sample groups.

The main purpose of the shopping mall customer survey was to identify the following characteristics:

- profile of shopping mall customers in terms of gender and social status (homogenous transport behaviours);

- characteristics of journeys undertaken to shopping malls, mainly with regard to starting point of journey, distance from the starting point to the facility, time of the trip choice of transport means;

- modal division into particular means of transport chosen by the shopping mall customers;

- distribution of types of facilities visited according to particular branch groups (kinds of stores) trades and services;

- data relating to shopping mall customer vehicle parking, most importantly with regard to time of parking, rotation of vehicles, occupancy of parking space.

The survey of shopping mall customers was conducted inside the facilities during opening hours (between 9.00am and 9.00pm). The questionnaire sheet was comprised of nine questions concerning transport related behaviours of shopping mall customers. 
The first question was about the respondent's gender and the next concerned their social and demographic status (relative to a group of transport behaviours). Four groups of respondents were defined on the basis of their demographic status:

- schoolchildren (a person aged over 9, attending primary school, junior high school or high school),

- student (full time or part time university/college student),

- employed person,

- unemployed person (an individual who is registered as unemployed, retired or has no job).

The third question related to the starting point of travel to the shopping mall, including (with the respondent's consent) address or postal code of the starting point. Four possible journey sources were indicated:

- home,

- work,

- another shopping mall,

- other places (facilities) - other facilities unrelated to workplaces and residency, including other stores, offices, doctor's surgeries, medical centres, schools, nurseries, hospitals.

Questions four and five were connected with the length of the journey to the shopping mall expressed in distance (kilometers) and travel time (minutes), respectively. Information relating to the duration of the respondents' stay in the shopping mall was covered in the sixth question. Question seven concerned the mode of transport chosen to visit the shopping mall. The following means of transport were considered:

- walk,

- bicycle,

- car (driver),

- car (passenger),

- public transport (including: bus, tram, trolleybus, private line bus, etc.).

Identifying the purpose of the visit to a given shopping mall was a very important part of the survey and was covered by the eighth question). To this end, the respondents could choose the following branch groups (trade-service types of retail outlet) located on the shopping mall premises (including examples of stores of particular types):

- fashion - shops with clothes and shoes for adults and children, with the exception of sports clothes or shoes; this group of stores includes the following brands: 'H\&M', 'Reserved,' 'Gino Rossi', 'Bershka,' 'Smyk', 'Mohito, 'Bytom', 'Vistula',

- multimedia - stores with household products and household equipment, electronic equipment, audio and visual appliances; this group of stores includes the following brands: 'idream', 'Komputronik', 'Media Markt', 'Euro RTV AGD', 'Saturn',

- supermarkets and hypermarkets - these stores include a large variety of products from different brands including a wide assortment of food products. The group of 
supermarkets includes such brands as: 'Piotr i Paweł, 'Alma', 'Dino', 'Mila,' 'Aldi'; and hypermarkets such as 'Auchan', 'Tesco,' 'E. Leclerc', 'Carrefour',

- cosmetics stores - shops with cosmetics, perfumes, body care articles. These include outlets such as: 'Rossman', 'Natura,' 'Douglas', 'Sephora', 'Super-Pharm,' 'Inglot',

- sports products - retailers which offer sports clothes, sports shoes and sports equipment. These include: 'InterSport', 'Puma', 'Adidas', 'Sizeer',

- culture - outlets such as newsagents, bookstores, art galleries and centres, such as 'Kolporter,' 'Empik,' 'Inmedio', 'Matras',

- house equipment - shops offering interior furnishings, such as furniture stores, stores with lamps, bathroom and kitchen equipment including: 'JYSK', 'Komfort', 'Home \& You',

- jewellery shops - shops which sell jewellery and watches; these include: 'W. Kruk', 'Timex', 'Swatch,' 'Pandora', 'Swarovski',

- dining establishments - a group of trading outlets including restaurants, fast food outlets, coffee shops and confectioners, such as: 'McDonalds', 'North Fisch', 'Pizza Hut', 'Cukiernia Sowa', 'Subway,' 'Burger Strefa',

- entertainment - including all kinds of entertainment facilities, such as cinemas and multiplex cinemas, bowling halls, arcade machines as well as entertainment events such as: exhibitions, festivals and other artistic events hosted by shopping malls,

- services - this group includes establishments located on the premises of a shopping centres such as: shoemakers, craft services, counselling services, post office, mobile phone services providers, private TV providers, clothes repair points, launderettes, florist shops, travel agents and departments of town offices,

- others-this groupincludes points which cannotbe classified within the abovementioned groups, such as: car washes, car mechanics, car rental establishments, yoga centres, fitness clubs, medical centres, cosmetic surgery centres, children's playgrounds.

In addition to the questionnaire surveys, it was necessary to determine the total number of people visiting the selected shopping malls on a typical weekday, during a twenty-four-hour period. In order to identify this figure, the following measurements were performed:

- number of people entering the facility,

- the number of vehicles entering the given shopping mall's parking facilities,

- the occupancy of vehicles entering the shopping mall premises.

The measurements listed above made it possible to identify the total number of people staying on the premises of a given shopping mall. These measurements were taken over the course of one day between $9.00 \mathrm{am}$ and $9.00 \mathrm{pm}$. The people who were involved in conducting these measurements stayed near all the entrances in order to obtain information on the total number of people entering or staying in a given shopping mall, in a given period of time. 


\section{The results of the survey on outlets attractiveness in shopping malls}

Travel generated by shopping malls is related to their attractiveness; in other words, it reflects a certain 'force' attracting customers to this specific facility. Therefore, in order to build a model of the travel generation potential of shopping malls, it is necessary to determine it characteristics. Thus, it was necessary to determine, in a manner that is as easy to understand as possible despite the complexity of the problem of shopping mall attractiveness, weights for particular groups of commercial outlets available in these shopping mall, reflecting their attractiveness for customers. The attractiveness of groups of commercial outlet ' $\mathrm{B}$ ' is defined as the ratio of the outlets choice frequency to be the customer journey destination to the considered facility (provided from the survey) to the share of gross leasable area (GLA) of this outlets in the entire gross lease area of the considered centre, expressed by equation:

$$
\gamma_{B}=\frac{1}{i i} \sum_{i=1}^{i i}\left\{\frac{\frac{n_{B, i}^{\prime}}{n_{i}^{\prime}}}{\frac{S c_{B, i}}{S c_{i}}}\right\},
$$

where:

$\gamma_{B}$ - mean weight of a given outlet attractiveness ' $\mathrm{B}$ ' in shopping malls in Poland [-]

$n_{B, i}^{\prime}$ - number of respondents - customers of shopping malls ' $\mathrm{i}$ ', who declared to have chosen a point or points of sale 'B' outlet (among others) as the destination of their journey in a given shopping mall

$n_{i}^{\prime}$ - number of respondents in a given shopping mall ' $i$ '

$S c_{B, i}$ - gross lease area of ' $\mathrm{B}$ ' brand in given shopping mall ' $\mathrm{i}$ ', $\left[\mathrm{m}^{2}\right]$

$S c_{i}$ - gross lease area of a given shopping mall ' $\mathrm{i}$, $\left[\mathrm{m}^{2}\right]$

ii - number of analysed shopping malls

Before the survey results from different towns were combined, nonparametric consistency tests of significance were performed in order to check whether the samples came from one general population [1]. For this purpose, twelve tests of rang sum for particular attractiveness weights ' $j$ ', relating to the distinct outlets were conducted. Five samples, coming from particular towns, were compared in each test. A level of significance of $\alpha=0.05$ was accepted for the tests. On the basis of the obtained results, it was found that the values of particular attractiveness weights $\gamma_{B}$ from different towns, did not significantly vary from each other; therefore, it can be assumed that they came from the same general population. The values of particular outlets attractiveness weights determined from all the surveys are presented in Table 1 . 
Table 1. List of calculated attractiveness weights for particular outlet

\begin{tabular}{|c|c|c|c|c|c|}
\hline \multicolumn{7}{|c|}{ Values of relative attractiveness of particular brands in the shopping malls determined } \\
on the basis of survey results
\end{tabular}

So determined attractiveness levels were also referred to particular groups of homogenous transport behaviors which enabled development of models for generation of travel potential for particular shopping malls of the analyzed groups of people. In this case, the attractiveness of particular ' $\mathrm{B}$ ' related outlets was determined in reference to a given group ' $\mathrm{n}$ ' in the following way:

$$
\gamma_{B(n)}=\frac{1}{i i} \sum_{i=1}^{i i}\left\{\frac{\frac{n_{B, n, i}}{n_{n, i}}}{\frac{S c_{B, i}}{S c_{i}}}\right\},
$$

where:

$\gamma_{B(n)}$ - mean attractiveness weight of given 'B' outlet groups for groups of homogenous transport behaviours ' $\mathrm{n}$ ' in shopping malls in Poland [-]

$n_{B, n i}^{\prime}$ - number of surveyed persons from a group of homogenous transport behaviours ' $\mathrm{n}$ ' who declared choosing 'B' outlet groups related destination of journey to a given shopping mall

$n_{n, i}^{\prime} \quad$ - number of respondents from group ' $n$ ' in given shopping mall ' $i$ '

The value of attractiveness weights calculated on the basis of the survey referred to particular groups of respondents is presented in Table 2. 
Table 2. List of attractiveness weights of particular outlet calculated for groups of respondents with homogenous transport behaviours

\begin{tabular}{|c|c|c|c|c|c|}
\hline \multicolumn{6}{|c|}{$\begin{array}{l}\text { Values of relative attractiveness of particular outlet in shopping malls with reference to particular groups o } \\
\text { respondents with homogenous transport behaviours determined on the basis of the survey results }\end{array}$} \\
\hline \multirow{3}{*}{ No. } & \multirow{3}{*}{ Type of outlets groups } & \multicolumn{4}{|c|}{ Group of respondents } \\
\hline & & $\begin{array}{l}\text { employed } \\
\text { person }\end{array}$ & student & schoolchildren & $\begin{array}{l}\text { unemployed } \\
\text { person }\end{array}$ \\
\hline & & $\gamma$ & $\gamma$ & $\gamma$ & $\gamma$ \\
\hline 1 & fashion & 1.212 & 1.261 & 1.651 & 1.264 \\
\hline 2 & multimedia & 1.685 & 3.372 & 2.094 & 1.178 \\
\hline 3 & supermarkets and hypermarkets & 1.072 & 1.190 & 1.089 & 1.039 \\
\hline 4 & cosmetics stores & 3.070 & 3.207 & 2.814 & 4,477 \\
\hline 5 & sports products & 2.695 & 3.996 & 7.224 & 1.876 \\
\hline 6 & culture & 2.527 & 3.933 & 6.232 & 3.272 \\
\hline 7 & house equipment & 7.129 & 2.838 & 3.624 & 5.783 \\
\hline 8 & jeweller shops & 5.430 & 4.002 & 2.704 & 6.705 \\
\hline 9 & dining establishments & 3.669 & 8.635 & 10.395 & 2.796 \\
\hline 10 & entertainment & 0.384 & 6.623 & 8.249 & 0.492 \\
\hline 11 & services & 3.698 & 2.908 & 3.542 & 2.422 \\
\hline 12 & others & 1.303 & 1.319 & 1.566 & 1.336 \\
\hline \multicolumn{6}{|c|}{ Symbols: $\gamma$ - value of attractiveness weight } \\
\hline
\end{tabular}

\section{The determination of the transport attractiveness model for a given shopping mall}

For transport models, the most important function enabling the determination of the number of journeys to a particular shopping mall to be the travel motivation, is the probability function of choosing a given object to be the journey destination. If visiting a shopping mall is assumed to be the motivation, the quantity can generally be expressed as follows $[3,6-8]$ :

$$
p_{C H(M)}=\left(\frac{Q_{C H(M)}}{Q_{M}}\right),
$$

where:

$p_{C H(M)}$ - probability of choosing a given object ' $\mathrm{CH}$ ' from all large shopping malls located in city (urban locations)'M' by inhabitants of town ' $M$ ' to be the journey destination

$Q_{M} \quad$ - number of all journeys to shopping malls in a given city (urban locations) ' $M$ ' [journey/24 hours]

$Q_{C H(M)}$ - number of journeys to a given shopping mall ' $\mathrm{CH}$ ' in city (urban locations) 'M' [journey/24 hours] 
The probability of a given facility being chosen by its inhabitants to be their journey destination, is usually defined as the relative value of the ratio of transport attractiveness and the function of journey resistance to a given object to other ratios of analogical objects which may be the journey motivation $[4,5,9]$. Thus, in the case of shopping malls, this probability is expressed in the following way, consistent with a general formula accepted in travel schedules $[3,6]$ :

$$
p_{C H(M)}=\frac{A_{C H(M)} \cdot f\left(D_{C H(M)}\right)}{\sum_{k=1}^{N_{O(M)}}\left(A_{k(M)} \cdot f\left(D_{k(M)}\right)\right)}, \quad\left(p_{C H(M)} \in<0 ; 1>\right),
$$

where:

$A_{\mathrm{CH}(\mathrm{M})}$ - attractiveness of a shopping mall ' $\mathrm{CH}$ ' in a given city (urban locations) ' $\mathrm{M}$ ' [journey/24 hours]

$f\left(D_{\mathrm{CH}(\mathrm{M})}\right)$ - function of journey resistance to a shopping mall ' $\mathrm{CH}$ ', in city (urban locations) 'M' [-]

$N_{O(M)} \quad$ - number of shopping malls located in a given city (urban locations) ' $\mathrm{M}$ ' [objects]

$f\left(D_{k(M)}\right)$ - function of journey resistance to a shopping mall ' $\mathrm{k}$ ', in city (urban locations) ' $\mathrm{M}$ ' [-]

$A_{k(M)} \quad$ - attractiveness of a shopping mall ' $\mathrm{k}$ ' in a given city (urban locations) ' $\mathrm{M}$ ' [journeys/24 hours]

The determination of journey resistance in transport models, presented in formula (5) is not very difficult because, for this purpose, the journey distance and duration time parameters can be used in an exponential function. However, the determination of transport attractiveness of particular objects, especially those that are significant in terms of traffic generation, poses many problems.

In seeking a function to express attractiveness of a shopping mall with regard to the generation of travel, a method of regression was used. For this purpose, a dependence formulated on the basis of the comparison of formulas was sought:

$$
A_{C H(M)}=\frac{Q_{C H(M)}}{f\left(D_{C H(M)}\right)}=f\left(S V_{j}\right),
$$$$
\left[\frac{\text { journey }}{\text { day }}\right](6)
$$

Whereas, the weighted area of a given shopping mall 'SVj' was accepted to be the variable defining the shopping mall attractiveness with the use of the previously determined weights for particular outlets:

$$
S V_{j}=\sum_{B=1}^{B B} S_{G L A, B, j} \cdot \gamma_{B}
$$

where:

$S V_{j} \quad$ - weighted area of the j-th shopping mall, $\left[\mathrm{m}^{2}\right]$

$S_{G L A, B, j}$ - gross lease area of brand 'B' located in the $j$-th shopping mall, $\left[\mathrm{m}^{2}\right]$ 
$\gamma_{\mathrm{B}}$ - coefficient of attractiveness of a given group of brands expressing the relative mean (in relation to the area ) frequency of a given brand choice to be the shopping mall journey destination, Table 1

B - given trade or service brand [-],

BB - number of trade and services outlet group types in a given shopping mall, [points]

The following form of function describing attractiveness of a shopping mall ' $\mathrm{CH}$ ' was determined:

$$
A_{\mathrm{CH}_{(M)}}=3.8904 \cdot S V_{C H(M)}^{0.7133},
$$$$
\left[\frac{\text { journey }}{\text { day }}\right]
$$

meeting boundary condition: $A_{\mathrm{CH}_{(M)}}=0$ for $S V_{\mathrm{CH}(M)}=0$,

The high value of the determination coefficient $R^{2}=0.66$ shows that the transport attractiveness of shopping malls has been correctly defined by the authors of this study. Figure 1 shows the results of the assumed function fitting to empirical data.

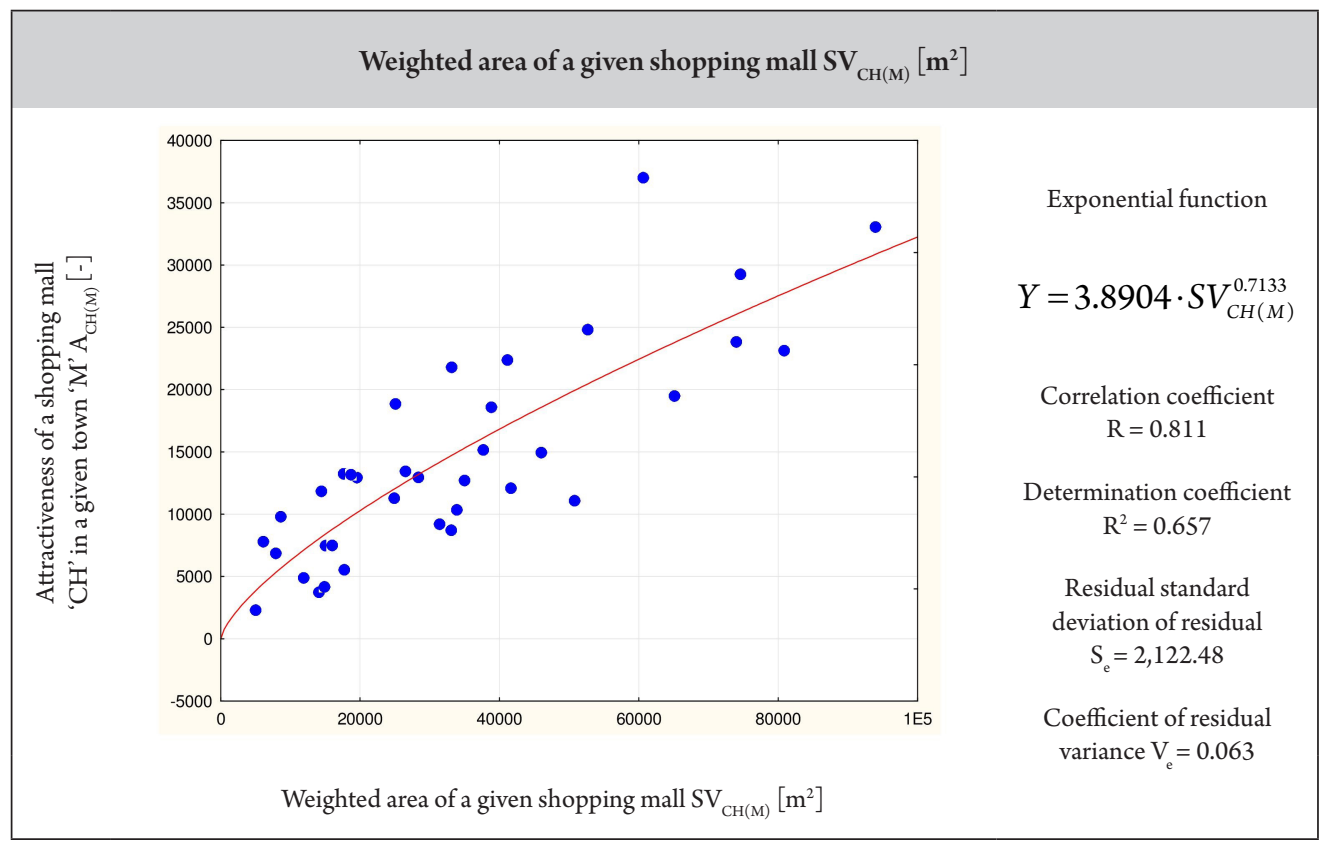

Fig. 1. Results of adjustment of the shopping mall assumed attractiveness function to empirical data

In the case of the determination of attractiveness for a given shopping mall for particular groups of persons with homogeneous transport behaviours, a similarly to equation no. 6 defined function was used: 


$$
A_{C H(M), m}=\frac{Q_{C H(M), m}}{f\left(D_{C H(M), m}\right)} f\left(S V_{j(m)}\right),
$$

where:

$Q_{C H(M), m} \quad$ - number of journeys to a given shopping mall ' $\mathrm{CH}$ ' in city (urban locations) 'M' by a group of persons with homogenous transport behaviors ' $m$ ', [journeys/24 hours]

$f\left(D_{\mathrm{CH}(M), m}\right)$ - function of journey resistance to a shopping mall ' $\mathrm{CH}$ ' in city (urban locations) 'M' by a group of people with homogenous transport behaviors ' $m$ ', [-]

$S V_{j(m)} \quad$ - weighed area of a given $\mathrm{j}$-th shopping mall for a given group of persons with homogeneous behaviors centrum ' $\mathrm{m}$ ' $\left[\mathrm{m}^{2}\right]$

$$
S V_{j(m)}=\sum_{B=1}^{B B} S_{G L A, B, j} \cdot \gamma_{B(m)},
$$

$S_{G L A, B, j}$ - gross lease area of a given outlet group 'B' located in $\mathrm{j}$ - th shopping mall $\left[\mathrm{m}^{2}\right]$

$\gamma_{B(m)}$ - coefficient of attractiveness of a given outlet group expressed by a mean relative (in relation to the area) frequency of choice of a given outlet group to be the destination of travel to a shopping mall of a given group of persons with homogeneous transport behaviors ' $m$ '; according to formula 1

B - given trade or service outlet group [-]

BB - number of kinds of trade and service outlet group [items]

Values of determination coefficients, for all groups of persons with homogeneous transport behaviours obtained for function (9) were similar to values of function $(8),\left(R^{2}>0.60\right)$.

\section{Conclusions}

1. The determination of shopping mall attractiveness presented in the study, including its weighted area $\mathrm{SV}_{\mathrm{CH}(\mathrm{M})}$, are highly comparable with the results of the values calculated from the model with the results of empirical experiments; this means that the attractiveness values were correctly calculated.

2. Simplicity is a significant feature of the proposed method for the calculation of a shopping mall attractiveness as it uses only one variable $\mathrm{SV}_{\mathrm{CH}(\mathrm{M})}$; calculations are easy because the values of this variable can be defined in a relatively simple way and requires only the values of gross lease area of particular branches and the attractiveness weights of these branches as defined in the study.

3. The attractiveness weights presented in Tables 1 and 2 and assigned to particular branch groups represent values determined from a questionnaire survey conducted on typical weekdays. It should be noted that on other days of the week (Friday, Saturday and Sunday) and days preceding holidays, the characteristics of attractiveness for particular branch groups can be different. Therefore, further research should be conducted to determine values of the considered weights for the remaining days of the week. 
4. Further research on changes in time (in successive years) of attractiveness weights of particular branches for groups of people with homogeneous transport behaviours should be conducted due to the constantly changing preferences of customers and the development of new types of trade and services being provided in large shopping malls.

\section{References}

[1] Greń J., Statystyka matematyczna. Modele izadania, Państwowe Wydawnictwa Naukowe, Warszawa 1982.

[2] Matuszak A., Matuszak Z., Określenie próby i jej liczności w badaniach pedagogicznych, General and Professional Education No. 2/2011, 33-39.

[3] PTV System GmbH, VISUM, Interactive Network Processing, Karlsruhe 2000.

[4] Sasidhar K., Vineeth Y., Subbarao S.S.V., Trip Attraction Rates of Commercial Land Use, Indian Journal of Science and Technology Vol. 9 Area Of Thiruvananthapram City, International Journal of Research in Engineering and Technology, Vol. 2, Issue 1, India 2016.

[5] Simmonds, D., Feldman O., Alternative Approaches to Spatial Modelling, Research in Transportation Economics 31 (1), 2011.

[6] Szczuraszek T., Kompleksowe badania $i$ analizy niezbędne do wyznaczenia kierunków rozwoju sieci drogowej miasta, Transport Miejski i Regionalny, 10/2007.

[7] Szczuraszek T., Bebyn G., Chmielewski J., Kempa J., Determination of numbers of people in groups of homogenous communicational behaviors for analysis of transportation needs, The Archives of Transport, No. 4, Vol. XV, 2003.

[8] Szczuraszek T., Bebyn G., Chmielewski J., Kempa J., Transport behaviour of inhabitants in big and medium cities of Poland, International Confernce "Modelling and Management in Transportation”, Kraków-Poznań, Poland 1999, 183-187.

[9] Uddin M., Hasan R., Ahmed I., Das. P., Uddin A., Hasan T., A comprehensive study on trip attraction rates of shopping centers in Dhanmondi area, International Journal of Civil \& Environmental Engineering, Vol. 12, No. 4, 2012. 